Article

\title{
Texts and Ritual: Buddhist Scriptural Tradition of the Stīpa Cult and the Transformation of Stūpa Burial in the Chinese Buddhist Canon
}

\section{Wen Sun}

East Asian Institute, Leipzig University, Schillerstr.6, 04109 Leipzig, Germany; bfsu.sunwen@hotmail.com

Received: 28 October 2019; Accepted: 2 December 2019; Published: 4 December 2019

\begin{abstract}
Chinese translations of Buddhist sūtras and Chinese Buddhist literature demonstrate how stüpas became acknowledged in medieval China and how clerics and laypeople perceived and worshiped them. Early Buddhist sūtras mentioned stüpas, which symbolize the presence of the Buddha and the truth of the dharma. Buddhist canonical texts attach great significance to the stupa cult, providing instructions regarding who was entitled to have them, what they should look like in connection with the occupants' Buddhist identities, and how people should worship them. However, the canonical limitations on stūpa burial for ordinary monks and prohibitions of non-Buddhist stūpas changed progressively in medieval China. Stūpas appeared to be erected for ordinary monks and the laity in the Tang dynasty. This paper aims to outline the Buddhist scriptural tradition of the stūpa cult and its changes in the Chinese Buddhist Canon, which serves as the doctrinal basis for understanding the significance of funerary stūpas and the primordial archetype for the formation of a widely accepted Buddhist funeral ritual in Tang China.
\end{abstract}

Keywords: Buddhism; Chinese Buddhist Canon; stūpa cult; Buddhist funeral; stūpa burial; Tang dynasty

\section{Introduction}

The Sanskrit term stūpa, originally referring to a funerary mound, pre-dates the flourishing of Buddhism in India. Buddhism transformed the original meaning of stūpa to a higher, transcendental level, something continually existent as a symbol of Buddhism and a ritual object (Pant 1976; Snodgrass 1988). Buddhist canonical texts attach great significance to the cult of stüpas, providing instructions regarding who was entitled to have them, what they should look like based on the occupants' Buddhist identities, and how people should worship them. As the symbolism of the presence of Buddha or other departed saints, stūpas spiritually reveal enlightenment, manifest compassionate ability, possess supernatural powers, and continue an ongoing relationship between the Buddha or other revered teachers with the laity or renunciants who worship stüpas (Ray 1994). The motivations of the stüpa cult mentioned in Buddhist sütras have been brought to light by some scholars, who concur that worshiping and making offerings at stūpas were practices leading people to enlightenment, Buddhahood, and liberation (Schopen 1985; Hirakawa 1987; Ray 1994). ${ }^{1}$ Apart from serving as containers for the cremated relics of the Buddha and the saints, stūpas subsequently developed new variants, such as commemorative stüpas erected for marking places of vital events or occasions during the Buddha's life and votive stūpas erected by clerics or laypeople to accumulate merit. Stüpas discussed in this paper focus on the type of stüpas serving a funerary function.

1 Reginald Ray suggests twofold goals of stūpa cult—favorable rebirth and perfect enlightenment-based on the Avolokita Sūtra (Ray 1994, p. 329). 
Chinese translations of Buddhist sūtras and Chinese Buddhist literature demonstrate how stūpas became acknowledged in medieval China and how clerics and laypeople perceived and worshiped them. Early interpreters coined the Chinese character $t a$ 塔 for stūpa when they translated Buddhist scriptures. When clerics and the literati strived to find substitutes to render the meaning of stuppas, the commemorative and funerary functions of ancestral temples (zumiao 祖廟) and traditional tombs became the predominant elements in illustrating stūpas. For instance, Daoxuan 道宣 (596-667) drew an analogy between caityas and ancestral temples rooted in ancestor worship, and he regarded stüpas as being similar to traditional tombs (T 1804, 40: 133c25-26). Ancestral temples were the places where the descendants could make offerings and pay homage to their ancestors, perpetuating the memory of their ancestors and reminding the descendants of the prestige of their patrilineal clans. Stūpas or caityas, as Buddhist shrines, represent the presence of the Buddha, symbolizing the truth of the dharma. Such an analogy reveals the typical perceptions of stüpas in medieval Chinese literature. By examining the equation of $t a$ 塔 with fen 墳 (tomb) in Yuance's 圓測 (aka. Wŏnch'ŭk, 613-696) Foshuo zaota gongde jingxu 佛説造塔功德經序 (Preface to the Sūtra on the Merits of Constructing a Stūpa, as Spoken by the Buddha), Tracy Miller suggests that Yuance appears to imply that the bodies of the deceased were similar to the relics of the Buddha, and the $d e$ 德 (virtue) essence of ancestors to be present in their remains was parallel to the dharma stored in the älayavijñanna (storehouse consciousness). However, it should be noted that fen was more than simply a burial mound, while stūpas had their ritual meanings (Miller 2018, pp. 82-103). The significant meanings of stūpas in particular historical contexts deserve great attention.

According to the original Buddhist sūtras, only specific eminent monks had the credentials of being worshiped in stüpas. However, the canonical limitations on stüpa burial for ordinary monks and prohibitions of non-Buddhist stūpas changed progressively in medieval China. During the Tang dynasty, stūpas underwent a diversified evolution. The most apparent change occurred in the sphere of people who were entitled to have stüpas. By the seventh century, the construction of funerary stūpas appeared to have been widely accepted in China. ${ }^{2}$ The connection established between tombs and stūpas in Chinese perceptions and the significance of stūpa cult in Buddhist sūtras functioned together to facilitate the acceptance of erecting funerary stupas as a funeral ritual among ordinary clerics and the laity.

To get a clear view of the transformation of the stupa cult in medieval China, it is necessary to figure out the tradition of the stupa cult in the early history of Buddhism in China. With the ascendancy of Buddhism and more and more Buddhists sütras being translated into Chinese. Buddhist works, such as treatises, commentaries, historical records, and the literature of various Chinese schools compiled by the contemporary Chinese clerics, can remind us of the perceptions produced in the new cultural context.

2 Past research has only identified stūpa burials for 17 eminent monks of the Six Dynasties chronicled in Huijiao's 慧晈 (497-554) work. The funerary stūpa thus did not make up a large portion of stūpa in the Six Dynasties (Sze 2012, p. 272). However, according to the Song gaoseng zhuan 宋高僧傳, 191 out of 419 monks of the Tang dynasty had funerary stūpa. More remarkably, unlike the scarcity of textual evidence in early medieval China, stüpa inscriptions unequivocally provide the epigraphic evidence about the erection of funerary stūpa in the Tang dynasty. The preeminent monk Daoping 道 憑 (488-559) established the Baoshao Monastery 寶山寺 on Mount Bao 寶山in the southeast of Shanying Town 善應鎮, 30 kilometers southwest of Anyang 安陽 in Henan Province. The stūpa forest carved in relief into a cliff there is regarded as the largest stūpa forest carved in relief (fudiao talin 浮雕塔林) in China. The funerary stūpa on Mount Bao and Mount Lanfeng 嵐峰山 significantly indicate the co-existence of funerary stūpas for clerics and laypeople in the Early Tang period. According to the archaeological study conducted by the Ancient Architecture Protection Institute of Henan in 1983, there are 80 caves executed in the form of stūpa-shaped niches (taxing kan 塔形龕) among the total 120 niches caved on the cliff of Mount Bao, while 73 stūpa-shaped niches are found on the cliff of Mount Lanfeng (Henan Research Institute for the Preservation of Ancient Architecture 1991, pp. 23 and 41). For more on the stūpa forest on Mount Bao, see (Ōuchi 1997; Adamek 2016). 


\section{The Stūpa Cult in Chinese Versions of Buddhist Sütras}

Since the third century, numerous Buddhist texts containing stories or discussions about the Buddha's nirvanna had been translated into Chinese. Sonya Lee has listed a section of 18 texts related to nirvanna available in the Chinese Buddhist canon of the medieval period (Lee 2010, p. 89). It is interesting to note that the functions of funeral services, viz., revealing the Buddha's continued spiritual presence and merit accumulated through worshiping stūpas, are emphasized in many texts. More importantly, apart from the stūpas erected for the Buddha, stūpas erected for Pratyekabuddhas, Arhats, and Cakravartins also bring great merit to sentient beings.

The Saddharmapundarīka Sūtra (Miaofa lianhua jing 妙法蓮花經), translated by Kumārajīva (334-413), contains a chapter entitled Jian baota pin 見寶塔品 (Beholding a Jeweled Stūpa). Kumārajīva, who came from Kucha, adopted the compound tamiao 塔廟 (stūpa shrine) in his translation (Hirakawa 1963). ${ }^{3}$ Bodhisattva Mahapratibhana asked the Buddha the reason a great-jeweled stūpa sprang from the earth and a voice came from within it. The Buddha explained the miracle as follows: "once a buddha named Abundant Treasures [Prabhūtaratna] made a great vow when he was treading the Bodhisattva-Way, saying, 'After I become a Buddha and am extinct, if in any country in the universe there be a place where the Law-Flower Sütra is preached, let my stüpa arise and appear there, in order that I may hearken to that sütra, bear testimony to it and extol it, saying 'Excellent'" (T 262, 9: 32c2-c7; Soothill 1930, pp. 157-68). ${ }^{4}$ The stūpa springing from the earth symbolizes the enlightenment and salvation of Prabhūtaratna. Moreover, Prabhūtaratna's presence verifies the truth of the Buddha's teachings, especially as expounded in the Lotus Sütra. After the Buddha opened the stūpa and others saw Prabhūtaratna, Prabhūtaratna invited the Buddha to sit next to him, which bore testimony to the timeless truth of the dharma. The stūpa symbolizes the truth that the Buddha preached. Seeing the stūpa signifies the discovery of one's own Buddha-nature (Niwano 1989, p. 102). Thereupon, all beings from all directions gathered around the stūpa and worshiped it (T 262. 9: 32c22). Notably, the description of the stūpa for Prabhūtaratna demonstrates the spiritual significance of stūpas in a Buddhist context, distinct from meanings of tombs and ancestral temples/shrines in traditional Chinese literature, although analogies are reflected in the translations. In the Tang dynasty, a stele inscription entitled Datang Xijing Qianfu si Duobao fota ganying beiwen 大唐西京千福寺多寶佛塔感應碑 文 (Stele of Stimulus and Response for the Prabhūtaratna Buddha's Stūpa of the Qianfu Monastery in the Western Capital of the Great Tang) states that a similar stūpa for Prabhūtaratna was erected in the Qianfu Monastery by the Buddhist monk Chujin 楚金. This statement verifies the acceptance of the spiritual significance of stūpas depicted in the Lotus Sütra in the Tang dynasty (QTW, juan 379, 1701). ${ }^{5}$

In the Lotus Sūtra, the stüpa manifested itself not only as a miraculous sign but also had the power to demonstrate the presence of Prabhūtaratna. Sākyamuni's account of the events that led up to the opening of the stūpa showed that Prabhütaratna's appearance was made possible by the vow he took at the moment of his nirvāna. Prabhütaratna sitting in the stūpa in a state of deep concentration might suggest that he was no different from the silent figure of the Buddha (T 262, 9: 32c2-c22). The stūpa provided the vehicle for Prabhūtaratna and the Buddha to be present within the world, which further verified the truth of Buddha's teachings in the sütra. Seeing the Buddha was the longed-for goal of the spiritual life surrounding the stūpa according to the Lotus Sütra.

3 Hirakawa examined previous Chinese translations during the second and third centuries, such as the Saddharmapundarika Sütra, which has several extant editions, and the Chinese edition Miaofa lianhua jing is one of them. He compared the Sanskrit sūtras with the Chinese translations to show that instead of using ta 塔, terms such as tamiao 塔廟 (stupa shrine), tasi 塔寺 (stūpa monastery), and fomiao 佛廟 (Buddhist shrine) frequently emerged in the Chinese Buddhist canon.

4 This motif frequently appeared in Buddhist votive steles in China, and this type of stūpa was designated as Duobao ta 多寶 塔. For more on the Prabhūtaratna Buddha's Stūpa from the perspective of Buddhist visual culture in caves and temples, see (Wang 2005, pp. 3-66).

5 This stele is now preserved in Xi'an Beilin Museum. The stele inscription states that when Chujin read the Baota pin 寶塔 品, he saw a stūpa springing from the ground. Chujin was inspired by such miracle and decided to erect a similar stūpa in the Qianfu Monastery. 
The Dìrghāgama Sūtra (Chang Ahan jing 長阿含經), translated by Buddhayaśas and Buddhasmṛti at the beginning of the fifth century, states that the Buddha himself expounded the sequence of the stupa burial to Ānanda. It is said that before the cremation, the body should be washed and bound with 500 layers of karpassa. Afterward, the flesh body wrapped with clothes would be put in a golden coffin filled with castor oil, and the coffin covered with thick cloth in preparation for the cremation. Then, the śarira should be collected and a stūpa erected at the crossroads, where the passersby could all see it. Accordingly, the living would obtain merit and would ascend to heaven after death (T 1, 1: 20b4-b11).

The Fo ban niheng jing 佛般泥恒經 and the Da ban niepan jing 大般涅槃經, translated from the Pāli version Mahāparinibbāna-sutta by Bai Fazu 白法祖 (Western Jin Dynasty) and Faxian 法顯 (337-422), respectively, and the Da ban niepan jing houfen 大般涅槃經後分 translated by Jñānabhadra from the Mahāyāna Mahāparinirvāna Sūtra in the middle of the seventh century, all contain Sākyamuni Buddha's exhortations to his disciple, Ānanda, on the need of the funeral ritual to conform to the procedures for Cakravartins. Division of relics and erection of stupas associated with other ritualized offerings, viz., flowers, incense, perfume, lights, silk, flags, and gems, were accepted as meritorious conduct to express veneration for the Buddha. Like the prescription in the Chang Ahan jing, the Da ban niepan jing also states that the Buddha himself authorized the erection of stūpas for the following kinds of people: Tathāgatas, Pratyekabuddhas, Arhats, and Cakravartins. He further specified that the stūpas erected for Tathāgatas or Cakravartins should be built at the crossing of four roads. In this way, votive stūpas erected for them could benefit all sentient beings (T 7, 1: 200a20-b3). More specifically, the Da ban niepan jing houfen delineates a clearer picture of the merit obtained through making offerings at the stūpas of Pratyekabuddhas, Arhats, and Cakravartins, respectively: making offerings at a Pratyekabuddha's stūpa would bring wonderful fruit (miaoguo 妙果) related to enlightenment and nirvāna; making offerings at an Arhat's stūpa would secure liberation; making offerings at a Cakravartin's stūpa would obtain boundless merit (T 377, 12: 903a9-a19). Buddhist monks, nuns, laymen, and laywomen who erect stūpas and worship the relics of the Tathāgata could benefit all sentient beings, releasing them from suffering in the world of sensuous desire, the world of form, and the formless world (sanjie 三界), and enabling them to obtain the absolute freedom (T 377, 12: 903a4-a5).

Erecting stūpas and making offerings at stupas would not only lead these who actually conduct the devotional practices to enlightenment, Buddhahood, and liberation. The spiritual achievements of the historical Buddha could be transferred to donors through the stupa cult; furthermore, the donor's merit could be transferred to all sentient beings through devotional practices. The Raśmivimala Viśuddhaprabhā Dhāran̄ī (Wugou jingguang da tuoluoni jing 無垢淨光大陀羅尼經) further affirms that merit could be obtained through constructing, maintaining, and making offerings to stūpas. Reciting the dhārañ $\bar{\imath}$ and putting a mantra in the stūpa as a devotional offering could dispose of hindrances, extend one's life, and help the departed obtain rebirth in the Tusita heaven and achieve Buddhahood (T 1024, 19: 718b17-b29 and 718c17-c19). The sūtra on merit and virtue entitled Foshuo zaota yanming gongdejing 佛説造塔延命功德經 (Sütra Expounded by the Buddha on the Merits of Constructing a Stūpa for Long Life), translated by Prajñā in the Tang dynasty, contains a similar narrative of extending one's life through constructing stūpas associated with reciting dhāraṇ̄ (T 1026, 19: 726a10-727c27).

Although the Foshuo guanding jing 佛説灌頂經 (Consecration Sūtra Expounded by the Buddha) has been defined as an apocryphal sütra, it obtained wide acceptance since its inception and was quoted as an authoritative source for funerary instructions in later Chinese Buddhist treatises and commentaries. ${ }^{6}$ More importantly, for our present purposes, it contributed to the formation

6 Such as the accounts of the Buddha's death and the recounting of attending the sick and the deceased in Baochang's 寶 唱 Jinglï yixiang 經律異相 (T 2121, 53: 17c8-17c29). The Fayuan zhulin 法苑珠林 adopts more content from the Foshuo guanding jing (T 2122, 53: 568b24-c2 and 745b15-c22). The fifth century Consecration Sütra employs abhiseka as a ritual of transmission in the lives of masters and disciples. Michel Strickmann has discussed the value of apocryphal sütras and makes 
of Buddhist funerary ideology. ${ }^{7}$ Notably, the sixth fascicle in the Foshuo guanding jing is concerned with stūpa worship when discussing the nidānas (cause) of funerary stūpas (zhongta yinyuan 塚塔因 緣). It describes the circumstances of funerary stūpas and provides sepulchral protective rites to guide the ordinary monks to protect their funerary stūpas from evil demons and spirits. The Buddha told his disciples that all the funerary stūpas were accompanied by good devas and evil demons and spirits (shan e gui shen 善惡鬼神). While the Buddha's stūpa enshrining his śarīra was protected by the four deva-kings of the four quarters and the eight classes of supernatural beings, the funerary stūpas for ordinary monks had no guardian devas (T 1331, 21: 513a28-c8 and 514c1-c3). Therefore, sepulchral protective rites should be conducted. The Buddha told his disciples that,

"At the moment of my nirvāna, I want to explain the nidānas and the avadāna [karmically significant deeds] of funerary stūpas for the great assembly, allowing the four grades to obtain salvation. The abhiseka stanza protects funerary stüpas for sages who have escaped from the chain of transmigration and for ordinary monks of the four directions, preventing them from being interfered with by other ghosts, demons, and those demons suffering from good death, evil death, or sudden death. Burning incense, making offerings at the funerary stūpas and reciting the spells in the four directions will expel these demons and evils respectively."

\section{我今於此大衆之中, 臨滅度時, 説是塚塔因緣譬喻, 令諸四輩各得其所。若諸賢聖四道果 人, 及諸凡夫塚塔之處, 皆應説是灌頂章句護於四方。不令他餘精魅鬼神, 善死惡死橫死鬼 神之所附著。燒香供養於塚塔上。向是四方説是章句時，諸鬼魔輩各自馳散.}

\section{(T 1331, 21: 514b17-b23)}

In order to protect the funerary stupas from the demonic forces, the power of the abhișeka stanza (guanding zhangju 灌頂章句) is emphasized here. It is plausible that this text might appear to be the earliest Chinese Buddhist scripture employing the term zhongta 塚塔 and that even the Buddha's stūpa was referred to as a funerary stūpa.

Apocryphal texts are deemed to derive from an assortment of translated texts, not only defined in Indian Buddhist sūtras but also blended in accordance with indigenous Chinese requirements. On the one hand, the Foshuo guanding jing admits the sanctity of the Buddha's stüpa in accordance with canonical scriptures. On the other hand, the depiction of funerary stüpas conveys contemporary conceptions regarding the stūpa cult in the monastic community to some extent. In this fascicle, it juxtaposes the stupa burial with inhumation, cremation, and water burial (T 1331, 21: 512b1-b4). It can be inferred from this text that, at least by the middle of the fifth century, the stupa burial had been accepted, and even ordinary monks were quite involved in these funerary practices. More importantly, the apocryphal scripture provides a particular entry announcing the significance of merit-making on behalf of the departed through funeral ceremonies:

On the day when a person is about to die or has already died, one should burn incense and lamps in the stūpa-monastery and hang up funeral banners, and have sūtras recited for three weeks. By doing this, the deceased who is in the intermediate region in the form of a small child and whose sins and good deeds have not yet been decided, will definitely, with this merit made in the hope of causing his or her spirit to be reborn in one of the Buddha lands of the ten directions, be able to take rebirth by virtue of such merit.

(cf. Cole 1996, p. 319)

a comprehensive research on the Consecration Sütra (Strickmann 1990, pp. 75-118). Wu Xiaojie has examined the formation of Consecration Sütra and its authorship (Wu 2011).

7 Alan Cole has devoted great attention to exploring the significance of the Consecration Sütra in forming the Buddhist funerary ideology (Cole 1996, pp. 317-20). 
若人臨終未終之日，當為燒香然燈續明。於塔寺中表刹之上，懸命過幡轉讀尊經竟三七日。 所以然者命終之人，在中陰中身如小兒，罪福未定應為修福。願亡者神使生十方無量刹土， 承此功德必得往生.

(T 1331, 21: 529c18-c23)

The Consecration Sütra is one of the first Buddhist texts providing directives for acquiring merit on behalf of the deceased (Strickmann 1990, p. 81). The third-party merit-making was widely acclaimed, since even those who converted at death or even died without believing in Buddhism would derive significant benefits from these funerary practices. Accordingly, it will be easy to understand that some ordinary people erected funerary stūpas for their sons who died at a young age. ${ }^{8}$ The stūpa-monastery here was depicted as a public place for people to conduct devotional practices to pray for blessings for the deceased. Hanging up funeral banners on stūpas and reciting sütras could transfer their merit to the deceased; accordingly, the deceased would obtain rebirth in the 10 Pure Lands. The stupa was perceived as a sacred entity connecting the living with the deceased.

In the sūtras discussed above, these stüpas, as an incarnation of the Buddha, are considered at all times sacred. They state the prescriptive paradigms of the stūpa cult related to the Buddha and the Buddhist saints. The significance of the transference of merit remains the same in these sūtras. Scriptures written in China, such as the Foshuo guanding jing, offer a broad view of the funerary practices related to stūpas, reflecting what was expected in a Buddhist funeral in fifth-century China.

\section{The Stüpa Cult in Chinese Translations of Vinayas}

Chinese translations of Buddhist scriptures served as a foundation for the spread of Buddhism in China. The largest part of the translation effort was finished in the medieval period. The translating centers were usually in the vicinity of main arteries and big cities, such as Luoyang 洛陽 and Chang'an 長安 in the Jin and Tang dynasties. During the Six Dynasties, as well as the Sui and Tang dynasties, lüxue 律學, which focused on studying the Buddhist disciplines, viz., Sarvāstivāda Vinaya (Shisonglü 十誦律), Dharmaguptaka Vinaya (Sifenlü 四分律), Mahāsanghika Vinaya (Mohesengqi lü 摩訶僧祇律), and Mahīśāsakas' Vinaya (Mishasaibu hexi Wufenlü 彌沙塞部和醓五分律), gained much popularity in the north-west. The vinaya texts serve as critical documentation on everyday life in and around monasteries. $^{9}$

The Shisonglï contains detailed descriptions concerning the stüpa cult. The Buddha allowed the householders, who supported orphans and the childless (jigudu jushi 給孤獨居士), to erect a stūpa for worshiping the Buddha's hair and nails. Then, the Buddha began to instruct the householder how to build the stupa by answering his questions: which color was allowed in painting the surface of the stuppa; how to place the canopies, doors, railings, and flowers; or whether the grotto, a mini stüpa, and pillars were allowed to be constructed (T 1435, 23: 351c11-352a21). From the Buddha's replies, the circumstances around and the structural form of a stūpa can be gleaned. Furthermore, rules concerning making offerings to stüpas, how to decorate stüpas, the use of flowers, incense, and festoons in worshiping stūpas constitute a fairly detailed picture of the stūpa cult ( $\mathrm{T}$ 1435, 23: 415b27-415c22). Similarly, according to the Chinese translation of the Dharmaguptaka Vinaya, when Śāriputra and Maudgalyāyana had entered parinirvāna, a donor said that one ought to get permission from the Buddha before one could erect stüpas for them. The Buddha allowed donors to construct stüpas and told them what the shape should look like and what material could be used. In the conversation between the Buddha and a donor, is described, on the one hand, what was

8 The stūpa-built in the 14th year of the Tianbao period (755), now extant in Dalaidian 大賴店 in Hebi 鶴壁 city of Henan Province-is a case in point. This stüpa was erected by Yi Shougui 尹守珪 for his son who died at 29 sui, with a stūpa inscription entitled Tang Longxi Yingong futuming bingxu 唐隴西尹公浮圖銘并序 (Tang wen shiyi 唐文拾遺, juan 21, 103).

9 Seishi Karashima has already dealt with the translation work related to stūpas described in the Vinayas. He provides comprehensive information about the structure of stüpas and the monastic activities in the Chinese translations of Vinayas (Karashima 2018). 
allowed at stūpas, such as constructing platforms, hanging banners and canopies, paving the path with stones, building walls or fences for stüpas, making offerings of food and drink, flowers, incense lamps, and making statues. On the other hand, climbing was forbidden and monks were not allowed to dance or perform music for the sake of worshiping stūpas, while laypeople were allowed to worship stūpas by dancing or performing music (T 1428, 22: 956c1-957a19). Both the Shisonglü and the Sifenlü reveal basic paradigms concerning how to construct sacred stūpas and how to worship them.

The chapter entitled Ming zasong baqufa 明雜誦跋渠法(Bhikșu-prakirnaka-vinaya) in the Chinese translation of the Mahāsanghika Vinaya (Mohesengqi lü 摩訶僧祇律) contains instructions how to build stūpas, especially how to erect a sacred stūpa, how to make offerings to them, and how to maintain them (Karashima 2018, p. 440). It is recorded that when the Buddha constructed a stūpa for Kāśyapa Buddha, he told monks that, "Making a donation of hundreds of thousands of piculs (or loads; dan 擔) of genuine gold is not equal to (the offering of) a ball of clay for building a buddha-stūpa with a respectful mind" (T 1425, 22: 497c9-c10; Karashima 2018, p. 440). After the stūpa was completed, the Buddha paid homage to it in order to pay respects to Kāśyapa Buddha. When monks asked how to pay homage to the stupa, the Buddha recited a similar verse: "People's making a donation of hundreds of thousands (of pieces) of gold does not match respectfully paying homage to a buddha-stūpa with a single good mind" (T 1425, 22: 497c9-c10; Karashima 2018, p. 441). The good mind played a pivotal role in building and paying homage to the stüpa. The Mohesengqi lü states a clear demarcation between sacred stūpas and ordinary ones. "When a samghārāma (monastery) is built, one should choose a suitable place, in advance, for a stūpa. A stūpa should not be located to the south nor west (of the monastery). It should be located to the east, (or) should be located to the north. The area of the Community is not allowed to transgress the area of the Buddha (i.e., stūpa). The area of the Buddha (i.e., stūpa) is not allowed to transgress the area of the Community." The stupa should be built on a high place with a vantage point; behaviors such as washing, dyeing, hanging robes, wearing sandals, covering one's shoulders, blowing one's nose, or spitting on the ground should be all prohibited (T 1425, 22: 498a10-a17; Karashima 2018, p. 443). Verses related to worshiping or blasphemy depicted in this Vinaya were aimed to maintain the sanctity of stūpas since the devotional practices at stüpas would bring welfare to sentient beings.

The stüpa constructed for Kāśyapa Buddha is also recorded in the Wufenlü, which stipulates that stūpas should only be constructed for the Tathāgatas, holy disciples, Pratyekabuddhas, and Cakravartins (T 1421, 22: 173a6-a8). Apart from rules concerning building and worshiping stūpas in the Chinese version of the Mohesengqi lü, the rule concerning for whom stupas could be erected was quoted as an authoritative source in many later Buddhist works—such as the Sifen lï shanfan buque xingshi chao 四分律刪繁補閶行事鈔 (A Transcription of Abridged Revisions in the Dharmaguptaka Vinaya), the Fayuan zhulin 法苑珠林 (Pear-forest of the Dharma Garden), and the Huayanjing tanxuan ji 華 嚴經探玄記 (Plumbing the Essence of the Avatamsaka Sütra)—to verify the statement that ordinary monks could be entitled to have stūpas. ${ }^{10}$ The rule concerning for whom stūpas could be erected states as follows:

The Buddha says that stūpas, built with discs, ${ }^{11}$ adorned with banners and canopies, can be erected for four kinds of people: Tathāgatas, Śrāvakas, Pratyekabuddhas, and Cakravartins. The dying bhiksu, if they [have attained the stage of] Srotāpanna should consult with Srotāpanna [to get the permission to erect stūpas], Sakridāgāmi, Anāgāmi, and Arhats should consult with Arhats. As for vinaya practitioners, dharma masters, bhiksu administering affairs of the monastery, the bhiksu of high virtue and prestige should consult with the seniors. For those who virtuously observe precepts, pay homage to the monks and painstakingly assist in the affairs of the monastery, stūpas can be erected.

10 The most pervasive example may be the case in the Huayanjing tanxuan ji 華嚴經探玄記, which employs the term “fanseng 凡 僧" (T 1733, 35: 262b19-b23).

11 The discs of a stūpa represent ceremonial parasols on a vertical pole (Harvey 1984, p. 74). 
世尊説四人應起塔, 起相輪, 懸施幡蓋, 如來、聲聞、辟支佛、轉輪聖王是。無常比丘，若 是須陀洹應語須陀洹，斯陀含、阿那含、阿羅漢應語阿羅漢。若言持律，若言法師，若言營 事，德望比丘應語長老。是人持戒賢善，多供養僧，執事有勞應與起塔.

(T 1425, 22: 444b18-b23)

Vinayas concerning stūpa construction continued to appear in the Tang dynasty. The Mūlasarvāstivāda Vinaya translated by Yijing 義淨 (635-713) in the early eighth century continued to give details on stüpa construction and the maintenance of stüpas. The Genben shuoyiqieyoubu pinaiye $z a s h i$ 根本説一切有部毘奈耶雜事 states different numbers of chattras (umbrella-like discs) in accordance with the ranks of clerics. A householder went up to the Buddha and asked him whether it was allowed to build stūpas for others apart from Śāriputra. The Buddha replied as follows:

"When a stūpa is constructed for the Tathāgata, it should be made completely as described above. When it is for a Pratyekabuddha, do not place a jeweled vase [on the pole]. When it is for an arhat, [only] four layers of discs should be used; for a non-returner, just three; for a once-returner, two layers of discs [should be used]; for a stream-enterer, one disc should [be used]. [A stūpa] for a virtuous layperson should be [constructed] only [up to] the 'flat head' [harmika] and without any disc [chattra]. [Stüpas] should be constructed in this way as the Lord has instructed.".

(cf. Karashima 2018, p. 461)

若如來造窣波者, 應可如前具足而作。若獨覺勿安寶瓶。若阿羅漢相輪四重; 不還至三 ; 一 來應二 ; 預流應一。凡夫善人但可平頭，無有輪蓋。如世尊如是應作.

(T 1451, 24: 291c9-c13)

Moreover, the location of stūpas also varied according to the Buddhist ranks. The Buddha should stay on the dharma-seat, and great disciples' stüpas should be on both sides of it. Stūpas of virtuous laypeople should be constructed outside the monastery (T 1451, 24: 291 c14-c16). Different from the prescription regulated for the clerics in the Sifenlü, the Genben shuoyiqieyoubu nituona 根本一切有 部尼陀那, also translated by Yijing, states that laypeople can climb stūpas to hang banners, canopies, and other items for worshiping, whereas monks are not allowed to climb stüpas. However, if there are no laypeople and novices (qiuji 求寂; Skt. śrāmenera), monks can climb stūpas only after washing their feet, anointing them with incense liquid or unguents, and thinking, "we are now going to worship the Great Master"; otherwise, one will be guilty of wrongdoing (T 1452, 24: 429c5-c11; Karashima 2018, p. 464).

Taking into account all the Vinayas discussed above, the prescriptive function makes stūpas erected for the Buddha or holy disciples present a hallowed manifestation and instill a sense of solemn into donors. Lofty halls and high buildings accompanied by jeweled bells, banners, canopies, and various precious items such as gold, silver, pearl, and crystal, and offerings such as lamps, incense, flowers irrefutably contribute to the establishment of the sanctity of the stūpas erected for the Buddha and other holy ones. Although the Mohesengqi lï gives little attention to the structure of stūpas and the offerings, the demarcation between the sacred and the profane is still clear. The Vinayas translated by Yijing in the Tang dynasty also indicate that the architectural structure and the location of stupas varied according to the rank of clerics, and even the liturgies related to stüpas varied between the clergy and laity.

\section{The Stīpa Cult and Buddhist Funerals in Chinese Buddhist Works}

Buddhist works written in China are especially valuable for what they can tell us of a truly Chinese form of Buddhism, offering a wide view of the acculturation and synthesis of Indian Buddhist elements on foreign soil. Lengthy quotations from Buddhist sütras, Vinayas, treatises, historical works, biographies of eminent monks, and a wide range of other sources provide knowledge on various 
Buddhist topics. Completed in 668, the Fayuan zhulin is such an encyclopedic compilation of scriptural passages by Daoshi 道世 (seventh century). Daoshi provided extensive discussion of Buddhist funerals in two of his main works-Zhujing yaoji 諸經要集 (Collections of Essentials from Sūtras) and Fayuan zhulin -in which he explicitly integrated the stūpa cult into the Buddhist funerals. The 20-fascicle compendium Zhujin yoaji seems to be an abridged version of Fayuan zhulin. Both texts have entire chapters on funerary concerns, entitled Songzhong bu 送終部 (Section on Sending off the Deceased) and Songzhong pian 送終篇 (Text on Sending off the Deceased), respectively. Many of the passages are excerpts quoted from earlier sütras and Vinayas. More remarkably, in the Fayuan zhulin, Daoshi drew on a wide range of sütra literature associated with his comments to elucidate the rituals concerning worshiping stūpas. On the one hand, he cited contents from the Chang Ahan jing, Shier yinyuan jing 十二因緣經 (Sütra of the Twelve Links of Causes and Conditions) and Mohesengqi lü to elucidate the construction of stuppas for specific buddhas, as well as the location and the circumstances for the erection of stüpas (T 2122, 53: 580a25-b15). On the other hand, unlike the quoted sütras and Vinayas, he clearly used the term fanfu 凡夫 to delineate that not only ordinary monks but also laypeople, who were regarded as prestigious, were all entitled to have stūpas built for them (T 2122, 53: 580a6-a7). Notably, the ordinary ones here refer to virtuous monks of prestige, which still complies with the criteria stipulated in the Mohesengqi lü shown above. For worshiping the funerary stūpas, Daoshi asserted that laypeople (baiyi 白衣) should worship all the funerary of the clerics (T 2122, 53: 999b14-15).

Daoxuan's A Transcription of Abridged Revisions in the Dharmaguptaka Vinaya, purportedly earlier than Daoshi's, is also very informative on dealing with Buddhist funeral practices. As is often the case, many of the passages were quoted from earlier sütras and Vinayas. Daoshi and Daoxuan agreed on many aspects of funeral practices. In the chapter entitled Zhanbing songzhong pian 瞻病送終篇 (Attending to the Sick and Sending off the Deceased), Daoxuan quoted the liturgical directions from the Sifenlï and the Mohesengqi lü respectively to delineate how to arrange burials for the deceased by erecting stūpas (T 1804, 40: 145b28-c5). Daoxuan's attention to "attending to the sick" and funeral ritual evinces the integration of the concept of Pure Lands into Buddhist funerals (Cole 1996, pp. 326-27; Koichi 2007, pp. 105-22). Daoxuan's discussion on the moment of death was aimed at providing instructions for dying monks who cared about the postmortem destination related to a superior rebirth, by emphasizing the moment of death as the important moment that would determine the circumstances of one's rebirth. Daoxuan extended the funeral ritual to every type of believers and practitioners. Any cleric, whether he was a vinaya reciter, a dharma master, or a meditation master, could be given the Pure Land funeral. The only difference concerned the eulogies, which the attendant monk should present according to the categories of practices in which the dying monk specialized. Furthermore, Daoxuan extended the sphere of the Buddhist funerals to laypeople. When someone was about to die, whether a cleric or a layperson, his or her close associates should stand by the bedside, watching over, and guarding that individual for the sake of helping him or her obtain a better rebirth (T 1804, 40: 144c6-144c9; Cole 1996, p. 326; Koichi 2007, pp. 118-19). Scriptural quotations are regular elements in Buddhist works, but for the above deathbed practices, Daoxuan stated that the practice he described was based on the Chinese tradition (Zhongguo ben chuan 中國本傳), which was emphasized three times in this chapter (T 1804, 40: 144a12-a13; 144a12; 144c6). Based on such a declaration, Alan Cole suggests that one difference between Daoxuan and Daoshi is that Daoxuan integrated the non-canonical elements into his discussion on Buddhist funerals (Cole 1996, p. 326). However, strictly following the discussion made by Daoxuan concerning the deathbed practices, it can be detected that what Daoxuan referred here was not non-Buddhist tradition but Chinese Buddhist tradition, which means that Daoxuan had admitted the existence of a well-established form of Chinese Buddhist funeral at that time and perceived it as equal to textual sources (Koichi 2007, pp. 105-22). Thus, when we go back to the Zhujing yaoji and Fayuan zhulin, the difference outlined by Alan Cole should be reconsidered.

In the Zhujing yaoji and Fayuan zhulin, the most remarkable example is a group of quotations from Chinese classics such as the Liji 禮記 (Books of Rites), the Zuozhuan 左傳 (Zuo Tradition), and the Huainanzi 淮南子 (Masters from Huainan) with respect to the idea of hun 魂 and po 魄. 
As Yü Ying-shih suggests, "ancient Chinese people generally believed that the individual human life consisted of a bodily part and a spiritual part" (Yü 1987, p. 364). From the sixth century BCE, the dual concept of soul emerged (Yü 1987, pp. 370-73). The spiritual soul ascended to heaven while the physical soul descended to the underworld at death. The dual soul is usually designated as hun 魂 and po 隗 in Chinese (Assandri 2013, pp. 3-7). Ritual practices appeared to aid the preservation of the soul. Tombs were built to placate the po souls, while shrines were built to propitiate the hun souls. ${ }^{12}$ The quotation of the idea of hun and po appearing at the beginning of Daoshi's discussion concerning the disposal of the deceased and Buddhist funerary ritual remained the same in both Zhujing yaoji and Fayuan zhulin (T 2123, 54: 178b21-c21; T 2122, 53: 999a3-b6). By quoting Chinese literature, Daoshi conjured up a picture of summoning the hun soul to reunite with the po soul through. Following the description of the disposal of the corpse based on the idea of hun and po, Daoshi enumerated four kinds of Buddhist funerary forms in the Western Regions and stated the rules concerning erection and worship of stūpas (T 2123, 54: 178c22-179a1; T 2122, 53: 999b8-b11). The underpinning of the idea of hun and po in Daoshi's Buddhist work reveals that clerics and the laity alike should venerate the departed souls (wangling 亡靈) of their parents and relatives, such as they pay homage to their masters. Such a statement concerning conventional truth (sudi 俗諦; samvrtti-satyatva) had been acclaimed in the Nirvāna Sūtra concerning the ritual of requiting favors (baoen 報恩) (T 2123, 54: 179a13-a14; T 2122, 53: 999b27-b28). Implicit in this argument is the claim that there is no division in funeral rites given to clerics and the laity of the period. It makes sense to assume that Daoxuan and Daoshi both contributed to the formation of monastic funeral rites in the early seventh century associated with the aspiration for a good rebirth through Buddhist funerals, which served as a pivotal mental impetus to inspire people to erect funerary stüpas for the deceased in this period and afterwards.

Yijing's Nanhai jigui neifa zhuan 南海寄歸内法傳 (Records of the Inner Law Sent Home from the Southern Seas), which provides an introduction to the Buddhist disciplines practiced in India in the seventh century, offers another view compared with the previous Chinese Buddhist texts. Yiying firmly condemned the "Confucianized" Buddhist funeral. Epigraphic evidence from the Tang dynasty demonstrates that clerics could wear mourning dress together with the laity during their masters' funerals, and they cried and wept as if they had lost their parents. Also, the laity was free to attend Buddhist funerals as disciples of the deceased (QTW, juan 262, 1174). ${ }^{13}$ However, in the section entitled Ni yisang zhi 尼衣喪制 (Regulations on Mourning Dresses of Clerics), Yijing said that there was someone collecting relics to erect stuppas for the deceased, which was designated as kūla (juluo 俱). These were small stūpas without discs. As a pious vinaya observer, Yijing clearly emphasized the demarcation between the sacred stūpas and the profane ones. He explicitly condemned those clerics who put on mourning dress for three years and cried many times a month during the Buddhist funerals. According to Yijing, such kind of practices should be ascribed to the tradition handed down from the Duke of Zhou, not to the excellent teaching of Śākyamuni Buddha (T 2125, 54: 216c16-c18). Yijing aimed to protect the sanctity of the stūpas from being desecrated by the rituals he defined as non-Buddhist. However, Yijing's accounts otherwise suggest that the Chinese Buddhist community had begun to formulate their Buddhist funerals before the Chanyuan qinggui 禪苑清規 (Rules of Purity for Chan Monasteries), compiled in the second year of the Chongning 崇寧 period (1103) by Zongze 宗 賾. It seems that by the middle of the seventh century there appeared an accepted Buddhist death ritual related to stüpas for the clergy and the laity alike.

12 It should be noted that one of the primary goals of traditional Chinese funerary rites was to keep the physical body and spirit together. As Ken Brashier suggests, hun and po were used interchangeably in funerary inscriptions during the Han dynasty and "great efforts were made to keep this entity housed in the tomb with the body at death" (Brashier 1996, pp. 125-58). Wu Hung suggests that with the center of ancestral worship shifting from temples to tombs of families and individuals, the hun no longer flew away to receive offerings in temples and a legitimate place for one's soul or souls would be his or her tomb (Wu 2009, pp. 21-41).

13 After the Chan master Puji 普寂 (651-739) died, the Director of Henan Commandery Pei Kuan 裴寬 (679-754) wore mourning dress with his wife to attend the funeral for Puji. 
Fazang 法藏 (643-712), known as the Third Patriarch of the Huayan School, was a Buddhist master contemporaneous with Yijing. In the Huayanjing tanxuan ji, Fazang quoted from authoritative sources such as the Dīrghägama Sütra and the Mahāsanghika Vinaya to delineate the stūpa burial. It is clear that Buddhist scriptures outlined the differences among stüpas according to the different Buddhist identities of the occupants. Notably, Fazang employed the term fanseng 凡僧 (ordinary monks) to refer to the clerics for whom stūpas could be erected according to the Mohesengqi lï. It is evident that these ordinary monks, like the fanfu 凡夫 in Daoshi's work, do not refer to all the Buddhist monks, and certainly exclude the laity. But it at least implies that both Daoshi and Fazang endeavored to make the stūpas accessible to more clerics. In actual practice, even the laity began to have funerary stūpas in the Tang dynasty. Additionally, compared with Daoshi's Fayuan zhulin, Fazang provided more extensive interpretations of the functions and meanings of erecting stūpas in the chapter entitled Yisong yuan 遺送緣 (Causes and Conditions of Sending off the Deceased). Apart from indicating similar contents concerning the superior realm of rebirth, the significance of making others have pure faith, and requiting favors, Fazang further pointed out that stūpa worship aided in concentrating one's mind, transferring merit, and eliminating the kleśa. More importantly, by erecting Buddhist stūpas could bring seven kinds of holy happiness of Brahmā (fanfu 梵福) and aid one eventually to obtain freedom from transmigration ( $\mathrm{T} 1733,35: 262 \mathrm{~b} 23-\mathrm{c} 5)$. This passage was also repeated in Chengguan's 澄觀 (ca. 737-838) work in the eighth century (T 1735, 35: 712b15-c2). Consequently, Fazang verified and enhanced the understanding that erecting stupas would bring boundless merit to sentient beings.

\section{Concluding Remarks}

The perceptions of stüpas witnessed an ongoing process of reconstruction. The connection between stüpas and the Buddha has been reiterated again and again in the Buddhist sütras, Vinayas, and treatises, which underpins the sanctity of the stüpas and reaffirms the entrenched merit of building and worshiping stūpas. In this respect, stūpas were considered at all times sacred. Compared with the Vinayas, Daoshi and Daoxuan's Buddhist works reveal that Buddhists of all ranks, lay or clerical, male or female, could receive Buddhist funeral ritual. Both Daoxuan and Daoshi connected the funeral practices with the aspiration of rebirth, while Daoxuan expressed a clearer Pure Land orientation. Compared to Buddhist suttras, the demarcation between eminent monks and ordinary monks appeared to have been broken up in Chinese Buddhist works. Stüpas could not be only erected were no longer reserved for the Buddha and the saints. Fanfu and fanseng frequently appeared in Chinese Buddhist works, which expanded the sphere for whom stüpas could be erected, in keeping with the regulations in the Vinayas such as the Mohesengqi liu.

Chinese Buddhist works appeared to attenuate the distance between the sacred and the profane, encompassing the ordinary monks and the laity in the realm of the stūpa cult. Stūpas could be erected for ordinary monks and the laity, and all stūpas deserve veneration. The tradition of the stupa cult provides the ideological basis for accepting stūpa as a funerary type. The symbolism of nirvāna and perfect enlightenment related to the Buddha and the saints served as the cardinal religious presuppositions for stūpa burial. The Tang dynasty was a flourishing period of stūpa burial, and with it, a new kind of inscription entitled taming 塔銘 (stūpa inscriptions) prospered as a distinctive literary form. Stūpa inscriptions appeared to be composed for both clerics and laypeople, who were given stūpa burials. However, the actual situation of stupa construction in the Tang dynasty embodied a more complicated aspect than the monastic disciplines prescribed in Buddhist sütras and Vinayas, since it was bound to function in a period of convergence of diverse influences. Be that as it may, the tradition of the stūpa cult and Buddhist funerals in the Buddhist canon provide the doctrinal basis for understanding the construction of funerary stūpas and the primordial archetype for the formation of a widely Buddhist funeral ritual in Tang China.

As Mircea Eliade has suggested, "it would be useless to discuss the structure of the sacred space without showing, by particular examples, how such a space is constructed and why it becomes qualitatively different from the profane space by which it is surrounded" (Eliade 1958, p. 15). 
By manifesting the sacred, any object becomes something else, yet it continues to remain itself, for it continues to participate in its surrounding cosmic milieu (op. cit., 12). ${ }^{14}$ A funerary stūpa can be venerated as a sacred entity when it no longer manifests itself as a common tomb, but as a symbol of Buddhahood or liberation. However, the significance of funerary stūpas is far more complicated, since the sacred-profane segregation cannot remain static. Although traditional conceptions of the afterlife such as the idea of hun were embodied in stūpa burial, funerary stūpas manifested themselves more than burial mounds. The soteriological mechanism predicated on perceptions of the afterlife introduced by Buddhism shaped people's motives in erecting funerary stüpas for the deceased. Clerics and laypeople formulated their own perceptions on account of their different identities in particular social contexts. The original religious meanings of stūpas erected for worshiping the Buddha were transformed into practical concerns for a better rebirth associated with the pervasive presence of funerary stūpas for clerics and laypeople in medieval China. The transformation of stüpa burial in China deserves further attention.

Funding: I acknowledge support from the German Research Foundation (DFG) and Universität Leipzig within the program of Open Access Publishing.

Conflicts of Interest: The author declares no conflict of interest.

\section{Abbreviations}

$\mathrm{T}$ Taishō hinshū daizōkyō 大正新脩大藏經, followed by text number, volume number, page number by register [a,b,c], and line number. Edited by Takakusu Junjirō 高楠順次郎 and Watanabe Kaigyoku 渡邊海旭, et al. Tokyo: Taishō issaikyō kankōkai, 1924-1932.

QTW Quan Tang wen 全唐文. Compiled by Dong Gao 董誥 (1740-1818). Beijing: Zhonghua shuju, 1983, rpt.

\section{References}

\section{Primary Sources}

Baoshan Lingquan si 寶山靈泉寺. Edited by Henansheng gudai jianzhu baohu yanjiusuo 河南省古代建築保護研 究所 (Henan Research Institute for the Preservation of Ancient Architecture). Zhengzhou: Henan renmin chubanshe, 1991.

Chang Ahan jing 長阿含經 (Dīrghāgama Sūtra). Translated by Buddhayaśas 佛陀耶舍 (ca.4th-5th cent.) and Buddhasmriti 竺佛念 (ca. 4th-5th cent.). T 1, 1 .

Da ban niepan jing 大般涅槃經 (Mahāparinibbāna-sutta). Translated by Faxian 法顯 (337-422). T 7, 1.

Da ban niepan jing houfen 大般涅槃經後分 (Mahāparinirvāna Sūtra). Translated by Jñānabhadra 若那跋陀羅 (ca. 7th cent.). T 377, 12.

Dafangguang Huayanjing shujuan 大方廣華嚴經疏卷. Chengguan 澄觀 (737-839). T 1735, 35.

Fayuan zhulin 法苑珠林. Daoshi 道世 (ca. 7th cent.). T 2122, 53.

Fo ban niheng jing 佛般泥恒經 (Mahāparinibbāna-sutta). Translated by Bai Fazu 白法祖 (ca. 3rd cent.). T 5, 1.

Foshuo guanding jing 佛説灌頂經. Translated by Śrīmitra 帛尸梨蜜多羅 (d.343). T 1331, 21.

Foshuo zaota yanming gongdejing 佛説造塔延命功德經. Translated by Prajñā 般若 (ca. 8th cent.). T 1026, 19.

Huayanjing tanxuan ji 華嚴經探玄記. Fazang 法藏 (638-715). T 1733, 35.

Genben shuoyiqieyoubu mudejia 根本一切有部目得迦 (Mūlasarvāstivāda Vinaya). Translated by Yijing 義淨 (635-713). $\mathrm{T} 1452,24$.

Genben shuoyiqieyoubu nituona 根本一切有部尼陀那 (Mūlasarvāstivāda Vinaya). Translated by Yijing. T 1452, 24. Genben shuoyiqieyoubu pinaiye zashi 根本説一切有部毘奈耶雜事 (Mūlasarvāstivāda Vinaya). Translated by Yijing. $\mathrm{T} 1451,24$.

14 Mircea Eliade points out the function of "hierophany" by which the sacred can manifest itself; however, it should be noted that although the hierophany reveals an absolute fixed point, it no longer enjoys a unique ontological status. More importantly, the hierophany ensures the communication with the world of the gods, distinguishing it from the profane world (Eliade 1958, pp. 21-24). 
Mishasaibu hexi wufenlü 彌沙塞部和䤈五分律 (Mahīśāsakas' Vinaya). Translated by Buddhajīva 佛陀什 (ca. 5th cent.) and Zhu Daosheng 竺道生 (355-434). T 1421, 22.

Miaofa lianhua jing 妙法蓮花經 (Saddharmapundarīka Sūtra). Translated by Kumārajīva. T 262, 9.

Mohesengqi lü 摩訶僧祇律 (Mahāsainghika Vinaya). Translated by Buddhabhadra 佛陀跋陀羅 (359-429) and Faxian. $\mathrm{T} 1425,22$.

Nanhai jigui neifa zhuan 南海寄歸内法傳. Yijing. T 2125, 54 .

Shisonglï 十誦律 (Sarvāstivāda Vinaya). Translated by Kumārajīva 鳩摩羅什 and Punyatrāta 弗若多羅 (Jin dynasty). $\mathrm{T} 1435,23$.

Sifenlü 四分律 (Dharmaguptaka Vinaya). Translated by Buddhayaśas佛陀耶舍 (ca. 4th-5th cent.) and Buddhasmṛti 筑佛念 (ca. 4th cent.). T 1428, 22.

Sifen lü shanfan buque xingshi chao 四分律刪繁補閣行事鈔. Daoxuan 道宣 (596-667). T 1804, 40.

Tang wen shiyi 唐文拾遺. Compiled by Lu Xinyuan 陸心源 (1838-1894). Beijing: Zhonghua shuju, 1983, rpt.

Wugou jingguang da tuoluonijing 無垢淨光大陀羅尼經 (Raśmivimala Viśuddhaprabhā dhāran̄ī). Translated by Mitraśānta 彌陀山 (Tang dynasty). T 1024, 19.

Yourao fota gongdejing 右繞佛塔功德經. Translated by Śikșānanda 實叉難陀 (652-710). T 700, 16.

Zhujing yaoji 諸經要集. Daoxuan. T 1804, 40.

\section{Secondary Sources}

Adamek, Wendi L. 2016. Meeting the Inhabitants of the Necropolis at Baoshan. Journal of Chinese Buddhist Studies 29: 9-49.

Assandri, Friederike. 2013. Examples of Buddho-Daoist Interaction: Concepts of the Afterlife in Early Medieval Epigraphic Sources. The Electronic Journal of East and Central Asian Religions 1: 1-38. [CrossRef]

Brashier, Kenneth E. 1996. Han Thanatology and the Division of 'Souls'. Early China 21: 125-58. [CrossRef]

Cole, Alan. 1996. Upside down/Right Side up: A Revisionist History of Buddhist Funerals in China. History of Religions 35: 317-20. [CrossRef]

Eliade, Mircea. 1958. The Sacred and the Profane: The Nature of Religion. Translated by Willard R. Trask. New York: Harcourt Brace Jovanovich.

Harvey, Peter. 1984. The Symbolism of the Early Stūpa. Journal of the International Association of Buddhist Studies 7: 67-93.

Hirakawa, Akira. 1963. The Rise of Mahāyāna Buddhism and Its Relationship to the Worship of Stupas. Memoirs of the Research Department of the Tōyō Bunko 22: 57-106.

Hirakawa, Akira. 1987. Stupa Worship. In The Encyclopedia of Religion. Edited by Mircea Eliade. New York: Macmillan Publishing, vol. 14, pp. 92-96.

Karashima, Seishi. 2018. Stūpas Described in the Chinese Translations of the Vinayas. Annual Report of The International Research Institute for Advanced Buddhology at Soka University 21: 439-69.

Koichi, Shinohara. 2007. The Moment of Death in Daoxuan's Vinaya Commentary. In The Buddhist Dead. Edited by Bryan J. Cuevas and Jacqueline I. Stone. Honolulu: University of Hawai'i Press, pp. 105-22.

Lee, Sonya S. 2010. Surviving Nirvana: Death of the Buddha in Chinese Visual Culture. Hong Kong: Hong Kong University Press.

Miller, Tracy. 2018. Translating the Ta: Pagoda, Tumulus, and Ritualized Mahāyāna in Seventh-Century China. Tang Studies 36: 82-120. [CrossRef]

Niwano, Nikkyō. 1989. Buddhism for Today: A Modern Interpretation of the Threefold Lotus Sutra. Tokyo: Kosei Publishing Company.

Ōuchi, Humio. 1997. Hōzan Reisenji sekkutsu tomei no kenkyū: Zui-Tō jidai no Hōzan Reisenji 寶山泉寺石窟塔 銘研究—隋唐時代寶山泉寺. Tōhōgakuhō 69: 316-71.

Pant, Sushila. 1976. The Origin and Development of Stupa Architecture in India. Varanasi: Bharata Manisha.

Ray, Reginald A. 1994. Buddhist Saints in India: A Study in Buddhist Values and Orientations. New York: Oxford University Press.

Schopen, Gregory. 1985. Two Problems in the History of Indian Buddhism: The Layman/Monk Distinction and the Doctrines in the Transference of Merit. Studien zur Indologie und Iranistik 10: 9-47.

Snodgrass, Adrian. 1988. The Symbolism of the Stupa. Ithaca: Cornell University Press. 
Soothill, William Edward. 1930. The Lotus of the Wonderful Law (or The Lotus Gospel) Miao-fa Lien Hua Ching. Oxford: Clarendon Press.

Strickmann, Michel. 1990. The Consecration Sutra: A Buddhist Book of Spells. In Chinese Buddhist Apocrypha. Edited by Robert E. Buswell. Honolulu: University of Hawai'i Press, pp. 75-118.

Sze, Tak Pui. 2012. Stūpas in Medieval China: Symbols of the Buddha, Sacred Buildings, or Tombs? Ph.D. Dissertation, The University of British Columbia, Vancouver, BC, Canada.

Wang, Eugene Y. 2005. Shaping the Lotus Stura; Buddhist Visual Culture in Medieval China. Seattle: University of Washington Press.

Wu, Hung. 2009. Enlivening the Soul in Chinese Tombs. RES: Anthropology and Aesthetics 55-56: 21-41.

Wu, Xiaojie. 2011. Da guanding jing xingcheng jiqi zuozhe kao 《大灌頂經》形成及其作者考. Huadong shifan daxue хиеbao 3: 105-11.

Yü, Ying-shih. 1987. 'O Soul, Come Back!' A Study in the Changing Conceptions of the Soul and Afterlife in Pre-Buddhist China. Harvard Journal of Asiatic Studies 47: 363-95. [CrossRef]

(C) 2019 by the author. Licensee MDPI, Basel, Switzerland. This article is an open access article distributed under the terms and conditions of the Creative Commons Attribution (CC BY) license (http://creativecommons.org/licenses/by/4.0/). 